\title{
Exploring Occupational And Strategic Drivers Of Individual Customer Orientation
}

Turkan Dursun, West Texas A\&M University, USA

Ceyhan Kilic, New York Institute of Technology, USA

\begin{abstract}
The aim of this study is to investigate occupational and strategic drivers and performance consequences of individual customer orientation in the marketing/selling context via a conceptual framework. The occupational drivers are job involvement, role ambiguity/conflict, job satisfaction, and organizational commitment and the strategic driver is market orientation. The performance outcomes are relationship development and individual performance. The proposed model was tested over a random sample of 2000 marketers from a broad spectrum of businesses. The final sample consisted of 189 usable responses. A structural equation modeling analysis was used for model specification and hypothesis testing. According to the study results, there is a positive and significant relationship between market orientation and customer orientation. Also, organizational commitment and role conflict impact customer orientation significantly and positively. The effects of role ambiguity and job involvement on customer orientation are negative and significant. The study results also revealed that higher levels of customer orientation lead to higher levels of relationship development and individual performance. Managerial implications and future research avenues were also discussed.
\end{abstract}

Keywords: customer orientation, job involvement, role ambiguity/conflict, job satisfaction, organizational commitment, performance

\section{INTRODUCTION}

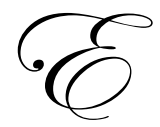

mployees of a market-oriented firm are ideally expected to be also market- or customer-oriented. Market orientation motivates employees to become more customer-oriented, more committed to their company and their job, and more satisfied with their job (Kohli and Jaworski 1990; Siguaw, Brown, and Widing 1994). Having a workforce with a strong market/customer orientation is especially important for a firm in the selling context. If a firm is market-oriented, it is more likely to take a planned action to train its sales employees to make them more market/ customer-oriented.

Since a marketer has a significant impact on the creating demand and establishing trust between the organization and the customer, the actions and behavior of a marketer and his/her orientation towards the customer become very significant and central from the organizational standpoint. If an organization aims to establish and/or maintain a competitive position in the marketplace and to develop long-term satisfactory relationships with its customers, it should definitely emphasize on understanding the factors that influence the customer-orientedness of its marketers.

\section{LITERATURE REVIEW}

Some studies have investigated customer orientation from the customer's point of view (e.g., Brown, Widing, and Coulter 1991; Michaels and Day 1985; Tadepalli 1995; O'Hara, Boles and Johnston 1991; Siguaw and Honeycutt 1995, etc.). These studies aim to obtain more objective evaluations or assessments of the degree of customer orientation of the firm's employees. Customers are expected to be less subjective in their evaluations of salespeople with whom they interact in sales situations or transactions (Michaels and Day 1985). A few studies have explored the extent of customer orientation and the customer orientation from both the seller's and buyer's 
perspectives (e.g., Dunlap, Dotson, and Chambers 1988; Jones, Busch, and Dacin 2003; Thomas, Soutar, and Ryan 2001).

Past research on customer-oriented selling has focused on measuring and/or modifying the effectiveness of customer-oriented selling and examining the relationship between customer-oriented selling behavior and sales effectiveness (e.g., Brown, Widding, and Coulter 1991; Dunlap, Dotson, and Chambers 1988; Howe, Hoffman, Hardigree 1994; Michaels and Day 1985; Saxe and Weitz 1982; Tadapalli 1995; Thomas, Soutar and Ryan 2001). To date, few studies have examined possible determinants of individual-level customer orientation. These potential determinants include role ambiguity, role conflict (Hoffman and Ingram 1991; Siguaw, Brown, and Widing, II 1994), job satisfaction (Hoffman and Ingram 1991; Pettijohn, Pettijohn, and Taylor 2002; Siguaw, Brown, and Widing, II 1994), job involvement (O'Hare, Boles, and Johnston 1991), internalization of service excellence, job competence, job autonomy (Peggei, Riccardo, and Rosental 2001), organizational commitment (O'Hare, Boles, and Johnston 1991; Pettijohn, Pettijohn, and Taylor 2002; Siguaw, Brown, and Widing, II 1994), sales training, sales skills (Pettijohn, Pettijohn, and Taylor 2002), and job tenure (O’Hare, Boles, and Johnston 1991).

In spite of its high importance, the number of studies on customer-oriented selling or individual-level customer orientation has been limited (e.g., Brown, Mowen, Donavan, and Licita 2002; O'Hare, Boles and Johnston 1991). Saxe and Weitz (1982) stated that "little empirical work has examined the effectiveness of customer-oriented selling and the factors influencing the extent to which salespeople engage in it" (p.344). O'Hare, Boles, and Johnston (1991) urged that "Although customer-oriented selling is an acknowledged practice, a complete understanding of is lacking" (p.61). O'Hare, Boles, and Johnston (1991) noted that "A review of work in the area of selling orientation/customer orientation indicates only limited research has examined the antecedents of this selling style" (p.64). Kelley (1992) urged that "very little research has investigated customer orientation and its antecedents" (p.30). According to Hoffman and Ingram (1991), "Little is known about the factors that affect customer-oriented behavior" (p.31). Recently, Brown et al. (2002) noted that "Despite the apparent importance of employees' customer orientation to the implementation of the marketing concept in the market-driven company, research on the construct has been limited" (p.111). All of these scholars have tried to draw attention to the lack of empirical research on customer orientation at the individual level and the importance of a better understanding of the customer-oriented selling concept in today's business world.

\section{MODEL DEVELOPMENT AND RESEARCH HYPOTHESES}

The objective of this study is to investigate the occupational (job-related) and strategic drivers and performance consequences of individual customer orientation in the marketing/selling context through a conceptual framework (See Figure 1). The suggested model consists of four parts: (1) job-related (occupational) antecedents of customer orientation, (2) strategic antecedent, (3) customer orientation, and (4) performance outcomes. Seven main research hypotheses were proposed associated with the suggested model.

\section{Occupational Drivers And Individual Customer Orientation}

This research study will explore the direct, independent effects of a number of occupational variables on customer orientation. These variables include job involvement, role ambiguity / conflict, job satisfaction, and organizational commitment.

\section{Job Involvement And Customer Orientation}

Job involvement is defined by Darden et al. (1993) as "the extent to which individuals identify psychologically with their work" (p.6). Brown et al. (1998) argued that "The more people identify psychologically with their jobs, the more challenging their personal goals are likely to be" (p.91). As employees have more job involvement, they are expected to set higher goals and standards for themselves to accomplish. The establishment of higher goals and standards creates more challenges for employees. This makes them more eager to succeed. They try to become and stay competitive over time. In order to achieve and maintain a higher level of long-term success, they need to focus on not only short-term financial goals but also long-term financial goals. 
Job-Related Factors

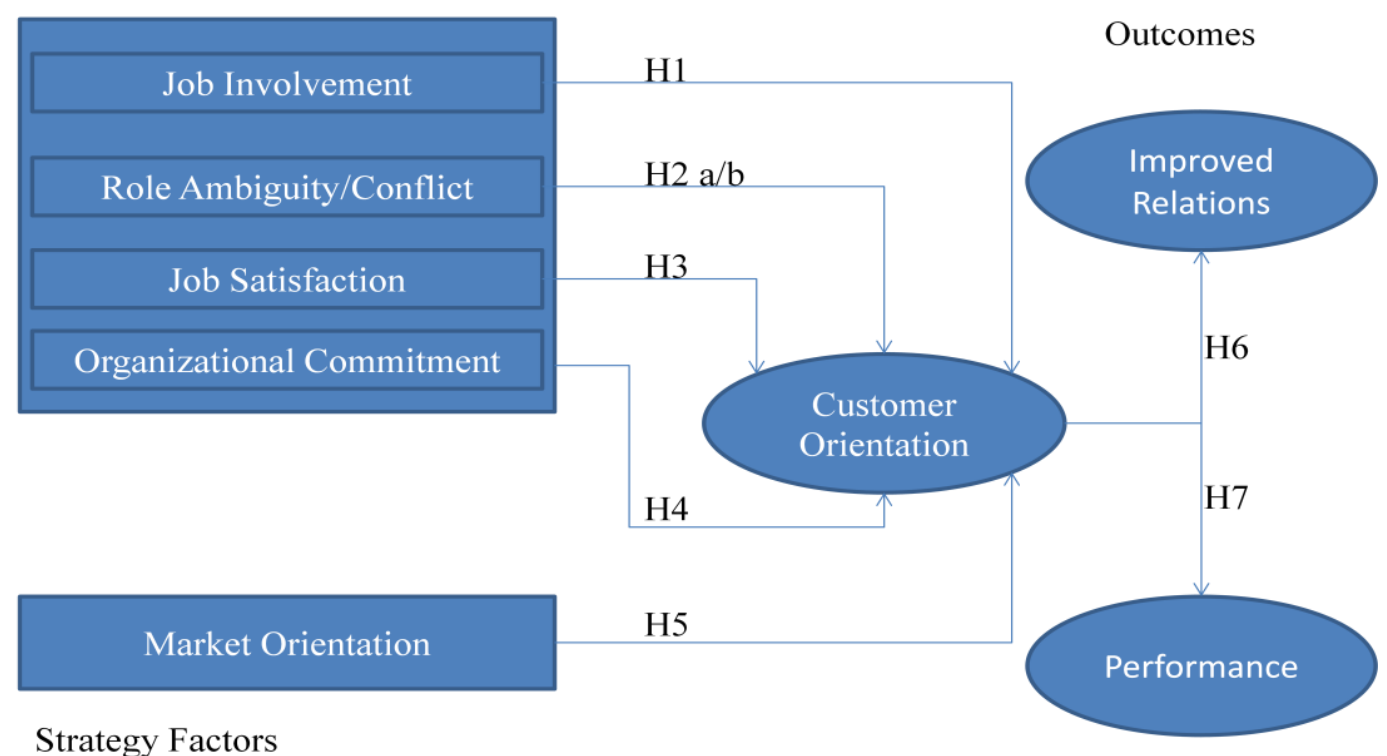

H1: The higher the job involvement of the marketer, the greater the customer orientation of the marketer.

\section{Role Ambiguity/Conflict And Customer Orientation}

Role ambiguity / conflict are undesirable aspects of a work environment. "Perceived role conflict occurs when a salesman believes that the expectations and demands of two or more of his role partners are incompatible and that he cannot simultaneously satisfy all the demands being made of him" (Churchill et al. 1976, p.326). Perceived role ambiguity occurs when the salesman feels he does not have the information necessary to perform his job adequately. Past research suggests that both role ambiguity (Roman and Iacobucci 2010) and conflict may have direct consequences for the organization. Brown and Peterson (1994) indicated role conflict/role ambiguity is likely to affect salesperson effort negatively.

H2a: The higher the role ambiguity of the marketer, the lower the customer orientation of the marketer.

H2b: The higher the role conflict of the marketer, the lower the customer orientation of the marketer.

\section{Job Satisfaction And Customer Orientation}

Job satisfaction is explained by "one's affective attachment to the job viewed either in its entirety (global satisfaction) or with regard to particular aspect (facet satisfaction; e.g., supervision)" (Tett and Meyer 1993, p.261). More specifically, job satisfaction is formally defined as "the pleasurable emotional state resulting from the appraisal of one's job as achieving or facilitating the achievement of one's job values" (Locke 1969, p.316). Employees who are satisfied with their jobs are expected to be more willing to adopt more customer-oriented behaviors (Farrell and Oczkowski 2009; Pettijohn et.al. 2007; Farrel 2005) and put extra effort to satisfy his/her customers.

H3: The greater the job satisfaction experienced by the marketer, the greater the customer orientation of the marketer. 


\section{Organizational Commitment And Customer Orientation}

Babakus et al. (1999) noted that organizational commitment can be considered as "the strength of the salesperson's involvement and loyalty to the organization" (p.61). Steers (1977) defined organizational commitment as "the relative strength of an individual's identification with and involvement in a particular organization" (p.46). According to Sager and Johnston (1989), organizational commitment is characterized by "an individual's identifying with the organization's goals and values, a willingness to put forth effort for the organization, and a desire to remain in the employ of the organization" (p.31). An employee with a strong organizational commitment identifies with his/her organization's goals and values and wants to be a part of his/her organization for a long time.

H4: The greater the organizational commitment of the marketer, the greater the customer orientation of the marketer.

\section{Strategic Drivers And Individual Customer Orientation}

The limited number of studies has explored the effect of organizational market orientation on individual customer orientation (e.g., Boles et al. 2001; Jones, Busch, and Dacin 2003; Siguaw, Brown and Widing II 1994). Market orientation was conceptualized by both Kohli and Jaworski (1990) and Narver and Slater (1990). Their conceptualizations are well-known and acknowledged by researchers. Both conceptualizations include an element which requires all of the firm's employees to focus on needs, wants, and preferences of their customers. These subdimensions are customer orientation (Narver and Slater 1990) and market intelligence generation (Kohli and Jaworski 1990). Either of these alternative dimensions is the key to a strong market orientation in an organization.

A strong market orientation leads to more satisfied employees who are more committed, motivated, and productive (Day 1998). A market-oriented organization requires its employees to be close to its customers and responsive to their needs and wants (Lam et al. 2010). Since employees of a market-oriented organization are generally highly motivated and committed (Day 1998), they are expected to implement the requirements of their employer completely. Thus, they are likely to become more customer-oriented or customer-focused. Also, Flaherty, Dahlstrom, and Skinner (1999) found that "employees perceiving a highly customer-oriented organization are likely to engage in those same types of customer-oriented behaviors themselves" (Flaherty, Dahlstrom, and Skinner 1999, p.11; Kohli and Jaworski 1990; Marshall 1985).

\section{Market Orientation And Customer Orientation}

Siguaw, Brown, and Widing II (1994) argued that "the firm possesses the means of influencing the customer orientation of its sales force and is rational in expecting the sales force to behave and respond to customer needs in manner that is congruent with the firm's market orientation. Therefore, it is reasonable to expect that the market orientation of the firm has a strong influence on the customer orientation of the sales force" (p.107). From the empirical aspect, Siguaw, Brown, and Widing II (1994) showed that there is a positive and significant relationship between market orientation and customer orientation. Organizational market orientation serves as an antecedent of individual customer orientation (Siguaw, Brown, and Widing II 1994). Also, Boles et al. (2001) reported the existence of a significant, positive relationship between a firm's customer orientation and customeroriented selling. However, Jones, Busch, and Dacin (2003)'s study revealed that there is no relationship between the firm's market orientation and salesperson's customer orientation. In brief, the findings of the past research on the nature of this relationship contradict.

H5: The greater the level of market orientation of the firm, the greater the level of customer orientation of its marketers.

\section{Customer Orientation And Relationship Development}

A possible link between customer orientation and relationship development has been explored by only a few studies (e.g., Williams and Attaway 1996). Williams and Attaway (1996) argued that "individual sales representatives can positively affect the organization's performance by utilizing a customer-oriented approach in 
establishing and maintaining relationships with customers" (p.39). Williams and Attaway (1996)'s argument suggests the existence of a positive connection between a customer-oriented approach and the establishment and maintenance of good relationships with customers. Moreover, Rush, Zahorik, and Keiningham (1996) indicated that "personal interaction component of services is often a primary determinant of the customer's overall satisfaction" (p.391). If the employee's interaction with customers is characterized as being customer-oriented or customerfocused, overall customer satisfaction may be increased. In turn, better customer satisfaction may lead to better longterm relations with customers. Empirically, Williams and Attaway (1996) found out that there is a positive and significant relationship between the salesperson's customer orientation and the development of buyer-seller relationship. Macintosh et al. (1992) claimed that "empirical evidence of the antecedents and process of relationship development is practically non-existent" (p.23). Therefore, it is believed that the investigation of customer orientation as a potential antecedent of relationship development would be a significant contribution to this line of research. On the basis of the empirical and conceptual evidence explained above, the following hypothesis was suggested:

H6: The higher the level of the marketer's customer orientation, the higher his/her level of relationship development.

\section{Customer Orientation And Performance}

MacKenzie (1993) thinks that performance is a representation of "a salesperson's overall contribution to the success of an organization" (p.70). Performance can be viewed as a product of the salesperson's abilities or aptitudes, skills (Churchill et al. 1985; Plank and Reid 1994), personality (Plank and Reid 1994), motivational state (Churchill et al. 1985), and other factors.

The number of studies that have investigated the link between customer orientation and performance is relatively large. In general, the past research found a positive and significant relationship between customer orientation and sales performance (Boles et al. 2001; Brown et al. 2002; McIntyre et al. 2000; Jaramillo and Grisaffe 2009). According to Williams and Spiro (1985), "Successful selling depends on successful interpersonal communication" (p.434). Salespeople who are able to communicate and interact with their customers better are more likely to score high on sales performance. Customer-oriented salespeople better understand and satisfy needs and wants of their customers. High customer satisfaction may result in customer loyalty, a high customer retention rate, or repeated sales. In sum, the past research suggests the existence of a positive connection between customer orientation and performance. Therefore, the following hypothesis appears to be appropriate in defining the customer orientation-performance link:

H7: The higher the level of the marketer's customer orientation, the higher the level of his/her performance.

\section{RESEARCH METHODOLOGY}

\section{Characteristics Of The Sample}

The suggested research model was tested with data obtained from a random sample of 2000 marketers from a broad spectrum of businesses within the manufacturing and non-manufacturing sectors. This study focuses on marketers as target respondents. A self-administered questionnaire was sent to each respondent along with a cover letter and a postage-paid return envelope. The final sample consisted of 189 usable responses resulting in a response rate of $9.45 \%$. Marketing managers were the largest group within the sample with 41.8 percent and followed by VP marketing (24.9\%), sales manager (13.8\%), marketing staff (13.8\%), sales staff (3.7\%), VP sales (1.1\%), and others $(1.1 \%)$.

\section{Data Analysis}

No non-response bias was found since there were no differences between the mean responses of the first and the last quartiles (Armstrong and Overton (1977). Principal component analysis with varimax rotation and Eigen value of 1 was conducted on each construct of the model to verify a single factor structure (unidimensionality of 
each construct). For each construct, only one factor structure was extracted. This indicates the evidence of unidimensionality of the model constructs. Reliability of each construct was evaluated using the coefficient or Cronbach Alpha $(\alpha)$. The reliability of each construct was higher than the cutoff value of 0.70 recommended by Nunnally (1978).

\section{Evaluation Of Model Fit}

A structural equation modeling (SEM) analysis via LISREL 8.5 was used for model specification and hypothesis testing. A confirmatory factor analysis (Joreskog and Sorbom 1993) was used to estimate the model parameters, to assess the model fit, and to test the suggested hypotheses. A moment covariance matrix of the observed variables was used for the analysis. During the confirmatory factor analysis, a number of other competing models were obtained by freeing and fixing the model parameters (Sharma 1996) or applying different estimation methods (i.e., unweighted least squares and generalized least squares) to the sample data. Maximum Likelihood (ML) estimation was utilized to estimate the model parameters. The fit between the suggested model and the sample data was found to be very good. Goodness-of-Fit Index (GFI) was 0.94 (greater than 0.90); CFI was 0.95 (greater than 0.90); and NFI was 0.95 (greater than 0.90).

\section{EMPIRICAL RESULTS AND DISCUSSION}

\section{Hypothesis Testing And Discussion Of Results} values.

Table 1 exhibits information related the suggested hypotheses, parameter estimates and their associated t-

Table 1. Parameter Estimates for the Hypothesized Links

\begin{tabular}{|c|c|c|c|}
\hline Hypothesized Link & Hypothesis & Estimate & t-value \\
\hline (+) job involvement to customer orientation & $\mathrm{H} 1^{*}$ & -0.6630 & $-7.260 *$ \\
\hline (-) role ambiguity to customer orientation & $\mathrm{H} 2 \mathrm{a}^{*}$ & -0.2480 & $-2.933^{*}$ \\
\hline (-) role conflict to customer orientation & $\mathrm{H} 2 \mathrm{~b}^{*}$ & 0.3560 & $4.156^{*}$ \\
\hline (+) job satisfaction to customer orientation & $\mathrm{H} 3$ & 0.0588 & 0.783 \\
\hline (+) organizational commitment to customer orientation & $\mathrm{H} 4 *$ & 0.4740 & $7.041^{*}$ \\
\hline (+) market orientation to customer orientation & $\mathrm{H} 5 *$ & 0.2050 & $3.105^{*}$ \\
\hline (+) customer orientation to relationship development & H6* & 0.4920 & $7.269^{*}$ \\
\hline$(+)$ customer orientation to performance & $\mathrm{H} 7 *$ & 0.3160 & $4.311^{*}$ \\
\hline
\end{tabular}

(*) Significant at 5\%, two-tailed test.

\section{Occupational Drivers}

The research results showed that job involvement positively affects customer orientation of the marketing personnel. It appears that an individual with a strong job involvement is likely to be more motivated to adopt customer orientation. As a person identifies psychologically with his job, he is likely to have more challenging personal goals to attain (Brown et al. 1998). Behaving in a more customer-oriented manner may be considered as one of the higher goals of the individual with high job involvement. Having a strong customer orientation will help him succeed in his job by building a strong customer base that will provide current and future sales for the firm.

According to the study results, there is a significant negative relationship between role ambiguity/conflict and customer orientation. It is true that when the roles are not well-defined, interactions and behavior patterns of employees will be more predictable and consistent (Floyd and Lane 2000). Employees who are unsure about what their actual roles on the job will be less effective on their jobs and be less committed to customer orientation. Yet, when they are well-informed about their job-related duties and responsibilities, they are likely to become more efficient and effective on the job (Floyd and Lane 2000). They may be more willing to increase the level of their customer orientation. 
According to the results of the study, high levels of job satisfaction lead to high levels of customer orientation. There is a positive relationship between job satisfaction and customer orientation. This finding is consistent with the results of earlier studies (e.g., Hoffman and Ingram 1991; Pettijohn, Pettijohn, and Taylor 2002). This finding suggests that when employees are satisfied with their jobs, they are expected to adopt high levels of customer orientation to be successful and stay on the job for a long-time. They will be more willing to satisfy their employees by emphasizing on establishing and maintaining good long-term relationships with them.

Finally, the study found a significant positive link between organizational commitment and customer orientation. This finding is consistent with those of earlier studies (e.g., Kelly 1992; O'Hare, Boles, and Johnston 1991; Pettijohn, Pettijohn, and Taylor 2002). Employees who have a strong commitment to their organization closely identify themselves with and become loyal to their organization. They enjoy to be a part of the organization and intend to stay with that organization for a long time. Because the survival of their organization will mainly be dependent on having a large number of satisfied long-term customers, committed employees may become more customer-oriented to satisfy the organization's customers. Also, a strong focus on customers may contribute to their success / performance on the job. As a result, having a strong customer orientation may be partly a product of having a strong commitment to the organization.

\section{Strategic Drivers}

In terms of the effect of market orientation on individual customer orientation, the study results revealed that high levels of organizational market orientation result in high levels of individual customer orientation. A strong organizational market orientation can be established and sustained through a strong customer orientation adopted by each individual within the organization. Thus, an organization with a high degree of market orientation is expected to actively encourage its employees to adopt the customer-oriented thinking and behavior.

\section{Performance Outcomes}

The study results suggest that higher levels of customer orientation result in higher levels of relationship development. This result is in agreement with Williams and Attaway (1996)'s finding that there is a positive and significant relationship between the salesperson's customer orientation and the development of buyer-seller relationship. Based on this finding, it is possible to argue that a strong customer orientation (i.e., personal interaction with customers) leads to better overall customer satisfaction (Rush, Zahorik, and Keiningham 1996) which, in turn, results in improved buyer-seller relationship.

It was found that there is a significant positive relationship between customer orientation and performance. This finding is consistent with the past research that found a positive and significant relationship between customer orientation and sales performance (Boles et al. 2001; Brown et al. 2002; McIntyre et al. 2000). This finding indicates that marketers who are able to communicate and interact with their customers better will have better performance scores (Williams and Spiro 1985). Marketers who have a strong customer orientation emphasize and better identify needs and wants of their customers. Their efforts translate into higher customer satisfaction, which, in turn, leads to more customer loyalty, higher customer retention rate, or more repeated sales.

\section{CONCLUSIONS AND MANAGERIAL IMPLICATIONS}

Since this study was conducted over a sample canvassing a wide spectrum of businesses, the study results may be generalizable to a wide range of companies. The study results provide valuable insights and practical implications for company managers.

First, the study results suggested a positive relationship between market orientation of the organization and customer orientation of marketers. This finding implies that developing a strong market orientation can benefit the organization by increasing its marketers' customer orientation. Marketing personnel has a profound role in connecting the organization to its customers (Ruekert and Walker 1987). Marketers' attitudes toward customers can directly affect customers' perceptions of the organization. Marketing personnel with a strong customer orientation 
are likely to create favorable perceptions of the organization in the minds of customers. This may lead to high levels of customer satisfaction, customer loyalty, and customer retention rate.

Second, in terms of the effects of job-related factors (i.e., job involvement, job satisfaction, role ambiguity / conflict, and organizational commitment) in the model, the study provides several valuable insights for managers. Managers should be aware of not only the effects of job-related variables on customer orientation, but also the possible interplays among these variables. First, while job involvement positively affects customer orientation, it also positively influences organizational commitment and job satisfaction. Given these complex links among the variables, it would be wise for the organization to invest heavily on increasing the level of job involvement of its employees. This would provide multiple benefits to the organization. Second, according to the study results, role ambiguity / role conflict negatively affect customer orientation, job satisfaction, and organizational commitment. The higher the level of role conflict, the higher the level of role ambiguity. These findings have very critical implications for managers. The company management should make sure that the roles, duties, and responsibilities of each employee are well-defined, and each employee is well-informed about his roles, duties, and responsibilities. Job descriptions of each position from bottom to top must be clearly stated and not be in conflict with each other. Given the negative consequences of high levels of role ambiguity and conflict at the individual level, the company management should be willing to get very creative in finding ways to reduce role ambiguity and conflict within their organization. Third, the study reveals that job satisfaction has positive effects on both customer orientation and organizational commitment. The company management should be aware of the fact that the employees with high job satisfaction levels will benefit the organization more. They will be more sensitive and responsive to needs and wants of the company's customers. They will identify closely with and be loyal to the organization. They are likely to be more committed to the organization. The company management should make every effort to make sure that its employees are satisfied with their jobs. Developing a strong internal marketing orientation within the organization may help the company management satisfy its employees at every level. Offering good salaries and benefits, establishing effective reward programs, and providing adequate job training for employees will help the organization accomplish its goals with regard to its employees' job satisfaction. Fourth, the study results showed that employees with high organizational commitment tend to be more customer-oriented. In order to increase their employees' organizational commitment, organizations should help their employees bond and identify with the organization. Establishing and maintaining a friendly, supportive work environment for all employees may enhance the chances that each employee will feel himself as an important part of the organization. Thus, they will more easily bond with and be more committed to the organization.

Finally, customer-oriented marketers perform better and contribute to the firm's efforts in developing excellent buyer-seller relationships. Therefore, firms should emphasize on promoting customer-oriented values and behaviors among their employees at all levels. They should periodically assess the level of their employees' customer orientation. In order to increase their employees' customer orientation, organizations should establish and maintain a friendly, supportive work environment for all employees may enhance the chances that each employee will feel himself as an important part of the organization. They should design training programs and establish reward systems to promote the levels of customer orientation of their employees.

\section{LIMITATIONS AND FUTURE RESEARCH SUGGESTIONS}

This study has some limitations that should be taken into consideration in future research studies. First, cross-sectional data was employed in the investigation of the suggested links in the model. This type of data has its own limitations. Cross-sectional data shows the links among the model variables at one point in time (Siguaw, Simpson, and Baker 1998). In other words, it gives a snapshot of the suggested links. In fact, some of these suggested links might be dynamic. Directions or signs of these links might change over time. Cross-sectional data does not reflect upon these dynamic links. Also, cross-sectional data does not provide information about the lagged effects of some variables in the model. Causal relationships, or dynamic links, or lagged effects among the model variables can be investigated via longitudinal studies.

Second, a wide spectrum of businesses were represented in the sample. This was opted for two purposes: (1) to generalize the research results to a larger set of businesses, and (2) to reduce industry-specific biases of the research results (Olson, Walker, and Ruekert 1995). However, the representation of a wide range of businesses in 
the sample may create a lot of noise and variation in the data. Some hypotheses may not have been supported because of a high level of noise in the data. Future studies may test the suggested model in the specific industry or business contexts by taking into consideration industry-specific differences or variations. For example, the suggested model may be tested over a sample of government employees (i.e., IRS or INS employees) from service sector.

Future research studies can incorporate additional possible outcomes or consequences of customer orientation into the suggested model. For example, job tension, job turnover rate and customer retention rate can be taken into consideration as possible outcomes of the individual-level customer orientation. Also, a possible link between customer orientation and ethical behavior toward customers can be investigated by future research.

\section{AUTHOR INFORMATION}

Dr. Türkān Dursun has been an assistant professor of marketing at West Texas A\&M University since 2006 and, prior to that, served as an instructor of marketing at New York Institute of Technology. Dr. Dursun earned a B.Sc. in engineering with an emphasis in management engineering at Istanbul Technical University. She obtained an M.B.A. in marketing from Fairleigh Dickinson University and an M.A. in economics from Old Dominion University. She also received a Ph.D. in marketing and international business from Old Dominion University. Dr. Dursun's research has been published in the proceedings of many national and international conferences and in peer-reviewed journals.

Dr. Ceyhan Kilic worked as an assistant professor of marketing at New York Institute of Technology. He also taught at DePaul University and Old Dominion University. Dr. Kilic earned a B.Sc. in engineering with an emphasis in management engineering at Istanbul Technical University. He obtained an M.B.A. in quantitative analysis from Fairleigh Dickinson University, and an M.A. in economics from Old Dominion University. He also received a Ph.D. in marketing and international business from Old Dominion University. Dr. Kilic's research has been published in the proceedings of many national and international conferences and in peer-reviewed journals.

\section{REFERENCES}

1. Armstrong, J. Scott and Terry Overton (1977), Estimating Nonresponse Bias in Mail Surveys, Journal of Marketing Research, 14 (August), 396-402.

2. Babakus, Emin, David W. Cravens, Mark Johnston, and William C. Moncrief (1999), The Role of Emotional Exhaustion in Sales Force Attitude and Behavior Relationship, Journal of the Academy of Marketing Science, 27 (Winter), 58-70.

3. Brown, Steven P., and Robert A. Peterson (1994), The Effect of Effort on Sales Performance and Job Satisfaction, Journal of Marketing, 58 (April), 70-80.

4. Brown, Steven P., William L. Cron, and John W. Slocum Jr. (2002) Effects of Trait Competitiveness and Perceived Intraorganizational Competition on Salesperson Goal Setting and Performance, Journal of Marketing, 62 (October), 88-98.

5. Brown, Tom J., John C. Mowen, D. Todd Donavan, and Jane W. Licata (2002) The Customer Orientation of Service Workers: Personality Trait Effects on Self-and Supervisor Performance Ratings, Journal of Marketing Research, 39 (February), 110-119.

6. Churchill, Gilbert A. Jr., Neil M. Ford, and Orville C. Walker, Jr. (1976), Organizational Climate and Job Satisfaction in the Salesforce, Journal of Marketing Research, 13 (November), 323-32.

7. Churchill, Gilbert A. Jr., Neil M. Ford, Steven W. Hartley, and Orville C. Walker, Jr. (1985), The Determinants of Salesperson Performance: A Meta-Analysis, Journal of Marketing Research, 22 (May), 103-18.

8. Cohen, Aaron (1993), Organizational Commitment and Turnover: A Meta-Analysis, Academy of Management Journal, 36 (5), 1140-1157.

9. Cohen, Joel B. (1967), An Interpersonal Orientation to the Study of Consumer Behavior, Journal of Marketing Research, 4 (August), 270-278.

10. Crosby, Lawrance A., Kenneth R. Evans, and Deborah Cowles (1990), Relationship Quality in Service Selling: An Interpersonal Influence Perspective, Journal of Marketing, 54 (July), 68-81. 
11. Darden, William R., Daryl McKee, and Ronald Hampton (1993), Salesperson Employment Status as a Moderator in the Job Satisfaction Model: A Framework of Reference Perspective, Journal of Personal Selling \& Sales Management, 13 (Summer), 1-15.

12. Dunlap, B. J., Michael J. Dotson, and Terry M. Chambers (1988), Perceptions of Real- estate Brokers and Buyers: A Sales-Orientation, Customer-Orientation Approach, Journal of Business Research, 17, 175-187.

13. Etzel, Michael J., Bruce J. Walker, William J. Stanton (2004), Marketing, $13^{\text {th }}$ Ed. New York, NY: McGraw-Hill Companies, Inc.

14. Farrell, Mark (2005), The Effect of a Market-Orientated Organizational Culture on Sales-Force Behavior and Attitudes, Journal of Strategic Marketing, 13(4), p. 261-273.

15. Farrell, Mark Anthony and Edward Oczkowski (2009), Service Worker Customer Orientation, Organization/Job Fit and Perceived Organizational Support, Journal of Strategic Marketing, 17(2) p. 149167.

16. Flaherty, Theresa B., Robert Dahlstrom, and Steven J. Skinner (1999), Organizational Values and Role Stress as Determinants of Customer-Oriented Selling Performance, Journal of Personal Selling \& Sales Management, 19 (Spring), 1-18.

17. Floyd, Steven W., and Peter J. Lane (2000), Strategizing Throughout the Organization: Managing Role Conflict in Strategic Renewal, Academy of Management Review, 25 (January), 154-77.

18. Gerbing, David and James Anderson (1988), An Updated Paradigm for Scale Development Incorporating Unidimensionality and its Assessment, Journal of Marketing Research, 25 (May), 186-92.

19. Hackman, J. Richard and Greg Oldham (1975), Development of the Job Diagnostic Survey, Journal of Applied Psychology, 60, 159-170.

20. Hoffman, K. Douglas and Thomas N. Ingram (1991), Creating Customer-Oriented Employees: The Case in Home Health Care, Journal of Health Care Marketing, 11 (June), 24-32.

21. Howe, Vince, K. Douglas Hoffman, and Donald W. Hardigree (1994), The Relationship between Ethical and Customer-Oriented Service Provider Behaviors, Journal of Business Ethics, 13, 497-506.

22. Hunt, Shelby D., and Robert M. Morgan (1994), Organizational Commitment: One of Many Commitments or Key Mediating Construct?, Academy of Management Journal, 37(December), 1568-87.

23. Jaramillo, Fernando, Douglas B. Grisaffe (2009), Does Customer Orientation Impact Objective Sales Performance? Insights from a Longitudinal Model in Direct Selling Journal of Personal Selling \& Sales Management, 29(2), p167-178.

24. Jones, Eli, Paul Busch, and Peter Dacin (2003), Firm Market Orientation and Salesperson's Customer Orientation: Interpersonal and Intrapersonal Influences on Customer Service and Retention in Business-toBusiness Buyer-Seller Relationships, Journal of Business Research, 56, 323-340.

25. Joreskog, Karl and Dag Sorbom (1996), LISREL 8: User's Reference Guide. Chicago: Scientific Software International, Inc.

26. Keillor, Bruce D., R. Stephen Parker, and Charles E. Pettijohn (1999), Sales Force Performance Satisfaction and Aspects of Relational Selling: Implications for Sales Managers, Journal of Marketing Theory and Practice, 7 (Winter), 101-115.

27. Kelley, Scott W. (1992) Developing Customer Orientation among Service Employees, Journal of Academy of Marketing Science, 20 (Winter), 27-36.

28. Kohli, Ajay K. and Bernard J. Jaworski (1990), Market Orientation: The Construct, Research Propositions, and Managerial Implications, Journal of Marketing, 54, 1-18.

29. Kotler, Philip (1980), Principles of Marketing. Englewood Cliffs, NJ: Prentice-Hall.

30. Lam, Son K., Florian Kraus, and Michael Ahearne (2010), The Diffusion of Market Orientation Throughout the Organization: A social Learning Theory Perspective, Journal of Marketing, 74(5), p. 61-79.

31. Lodahl, Thomas M. and Mathilde Kejner (1965), The Definition and Measurement of Job Involvement, Journal of Applied Psychology, 49 (February), 24-33.

32. MacKenzie, Scott B., Philip M. Podsakoff, and Richard Fetter (1993), The Impact of Organizational Citizenship Behavior on Evaluations of Salesperson Performance, Journal of Marketing, 57 (January), 7080 .

33. Macintosh, Gerard, Kenneth A. Anglin, David M. Syzmanski, and James W. Gentry (1992), Relationship Development in Selling: A Cognitive Analysis, Journal of Personal Selling and Sales Management, 12 (Fall), 23-34. 
34. Michaels, Ronald E. and Ralph L. Day (1985) Measuring Customer Orientation of Salespeople: A Replication with Industrial Buyers, Journal of Marketing Research, 22, 443-446.

35. Noerager, Jon P. (1979), An Assessment of CAD-A Personality Instrument Developed Specifically for Marketing Research, Journal of Marketing Research, 16 (February), 53-59.

36. Nunnally, Jum C. (1978), Psychometric Theory. $2^{\text {nd }}$ Ed. New York: McGraw Hill.

37. O'Hara, Bradley S., James S. Boles, and Mark W. Johnston (1991), The Influence of Personal Variables on Salesperson Selling Orientation, Journal of Personal Selling \& Sales Management, 11 (Winter), 61-67.

38. Peccei, Riccardo and Patrice Rosental (2001) Delivering Customer-Oriented Behavior through Empowerment: An Empirical Test of HRM Assumptions, Journal of Management Studies, 38, 831-857.

39. Pettijohn, Charles E., Linda S. Pettijohn, and R. Stephen Parker (1997), An Exploratory Analysis of the Impact of Salesperson Customer-Orientation on Sales Force Productivity, Journal of Customer Services in Marketing and Management, 3 (4), 5-24.

40. Pettijohn, Charles E., Linda S. Pettijohn, and A. J. Taylor (2002), The Influence of Salesperson Skill, Motivation, and Training on the Practice of Customer-Oriented Selling, Psychology and Marketing, 19 (September), 743-757.

41. Pettijohn, Charles E., Linda S. Pettijohn, and A. J. Taylor (2007), Does Salesperson Perception of the Importance of Sales Skills Improve Sales Performance, Customer Orientation, Job Satisfaction, and Organizational Commitment, and Reduce Turnover? Journal of Personal Selling \& Sales Management, 27(1), p75-88.

42. Plank, Richard E. and David A. Reid (1994), The Mediating Role of Sales Behaviors: An alternative Perspective of Sales Performance and Effectiveness, Journal of Personal Selling \& Sales Management, 14 (Summer), 43-56.

43. Rhoads, Gary K., Jagdip Singh, and Phillips W. Goodell (1994), The Multiple Dimensions of Role Ambiguity and Their Impact upon Psychological and Behavioral Outcomes of Industrial Salespeople, Journal of Personal Selling \&Sales Management, 14 (Summer), 43-56.

44. Rich, Gregory A. (1997), The Sales Manager as a Role Model: Effect on Trust, Job Satisfaction, and Performance of Salespeople, Journal of the Academy of Marketing Science, 25 (4), 319-328.

45. Roman, Sergio and Dawn Iacobucci (2010), Antecedents and Consequences of Adaptive Selling Confidence and Behavior: A Dyadic Analysis of Salespeople and Their Customers, Journal of the Academy of Marketing Science, 38(3), p. 363-382.

46. Rozell, Elizabeth J., Charles E. Pettijohn, R. Stephen Parker (2004), Customer-Oriented Selling: Exploring the Roles of Emotional Intelligence and Organizational Commitment, Psychology \& Marketing, 21 (June), p. 405-425.

47. Rust, Roland T., Anthony J. Zahorik, and Timothy L. Keiningham (1996), Service Marketing. New York: HarperCollins.

48. Sager, Jeffrey K., and Mark W. Johnston (1989), Antecedents and Outcomes of Organizational Commitment: A Study of Salespeople, Journal of Personal Selling \& Sales Management, 9 (Spring), 3041.

49. Sargeant, A. and M. Mohamad (1999), Business Performance in the UK Hotel SectorC Does It Pay to Be Market Oriented, The Service Industries Journal, 19 (3), (July), 42-59.

50. Saxe, Robert and Barton A. Weitz (1982), The SOCO Scale: A Measurement of the Customer Orientation of Sales People, Journal of Marketing Research, 19, 343-351.

51. Sharma, Subash (1996), Applied Multivariate Techniques. New York: John Wiley \& Sons, Inc.

52. Siguaw, Judy A., Gene Brown and Robert E. Widing, II (1994), The Influence of the Market Orientation of the Firm on Sales Force Behavior and Attitudes, Journal of Marketing Research, 31 (February), 106-116.

53. Steers, Richard M. (1977), Antecedents and Outcomes of Organizational Commitment, Administrative Science Quarterly, 22 (March), 46-56.

54. Swenson, Michael J., and Joel Herche (1994), Social Values and Salesperson Performance: An Empirical Examination, Journal of the Academy of Marketing Science, 22 (Summer), 283-39.

55. Tett, Robert P., and John P. Meyer (1993), Job Satisfaction, Organizational Commitment, Turnover Intention, and Turnover: Path Analyses Based on Meta Analytic Findings, Personnel Psychology, 46, 25993. 
56. Thomas, Raymond W., Geoffrey N. Southar and Maria M. Ryan (2001), The Selling Orientation-Customer Orientation (S.O.C.O.) Scale: A Proposed Short Form, Journal of Personal Selling \& Sales Management, 21, p. 63-69.

57. Walker, Orville C. Jr., Gilbert A. Churchill Jr., Neil M. Ford (1977), Motivation and Performance in Industrial Selling: Present Knowledge and Needed Research, Journal of Marketing Research, 14 (May), 156-168.

58. Walker, Orville C. Jr., Gilbert A. Churchill Jr., Neil M. Ford (1975), Organizational Determinants of the Industrial Salesman's Role Conflict and Ambiguity, Journal of Marketing, 39 (January), 32-39.

59. Weld, L. D. H. (1917), Marketing Functions and Mercantile Organization, American Economic Review, 7 (June), pp. 306-318.

60. Williams, Michael R., and Jill S. Attaway (1996), Exploring Salesperson's Customer Orientation as a Mediator of Organizational Culture's Influence on Buyer-Seller Relationships, Journal of Personal Selling \& Sales Management, 16, Number 4, 33-52.

61. Williams, Kaylene C. and Rosann L. Spiro (1985), Communication Style in the Salesperson-Customer Dyad, Journal of Marketing Research, 22 (November) 434-442. 